KONSTRUKTIVISME, Vol. 7, No. 2, Juli 2015

p-ISSN: 1979-9438, e-ISSN: 2445-2355

FKIP Universitas Islam Balitar, Blitar

Web: konstruktivisme.unisbablitar.ejournal.web.id

\title{
HUBUNGAN PERSEPSI PENERAPAN METODE TGT, TEKNIK REWARD AND PUNISHMENT \\ DAN MOTIVASI BELAJAR TERHADAP HASIL BELAJAR \\ SISWA KELAS V SDN I NGREJO TULUNGAGUNG
}

\author{
Hendrik Eko Prasetiyo \\ Universitas Islam Balitar \\ JI. Mojopahit No. 2-4 Blitar \\ Email: hendrikngepoh@gmail.com
}

\begin{abstract}
The objective of this study is to analyze relationship between perception in implementing TGT, Reward and Punishment techniques, learning motivation toward learning achievement in Civic education subject. The study took place in SDN I Ngrejo Tulungagung assigning the 34 fifth graders. This study used correlational design and data were collected using questionnaire and test. Data were analyzed using multiple regression techniques. The study found that (1) positive relationship between TGT, reward and punishment and learning achievement exists at .946; (2) positive relationship between learning motivation and learning achievement is .965; (3) positive relationship altogether between TGT, reward and punishment, and learning motivation towards learning achievement is .844 .
\end{abstract}

Keywords: TGT, reward and punishment, learning motivation.

\begin{abstract}
Abstrak
Tujuan penelitian ini adalah menganalisis hubungan persepsi penerapan metode TGT, teknik Reward and Punishment serta motivasi belajar terhadap hasil belajar PKn 34 siswa kelas V di SDN I Ngrejo Tulungagung. Jenis penelitian ini adalah korelasi dan data dikumpulkan menggunakan angket dan tes. Data dianalisis menggunakan regresi berganda. Hasil penelitian menunjukkan: (1) Terdapat hubungan positif penerapan metode TGT, Reward and punishment dengan peningkatan hasil belajar siswa pada 0,946 ;

(2) Terdapat hubungan positif antara motivasi belajar dengan hasil belajar siswa dengan koefisien korelasi 0,965; (3) Terdapat hubungan positif secara bersama-sama antara metode TGT, reward and punishment dan motivasi belajar terhadap hasil belajar siswa, dengan koefisien korelasi berganda sebesar 0,844.
\end{abstract}

Kata Kunci: metode TGT teknik Reward, motivasi, hasil belajar.

Pemilihan Metode dalam proses belajar mengajar diduga merupakan faktor yang dominan terhadap motivasi dan hasil belajar siswa, khususnya untuk kalangan peserta didik di tingkat Sekolah Dasar. Metode 
yang efektif, kreatif dan menyenangkan sangat perlu dikuasai oleh guru di sekolah dasar. Salah satu metode yang sering dikaji secara ilmiah adalah penggunaan metode Team Games Tournament (TGT). Seperti yang dikemukakan dalam skripsi Yudianto, Arif (2001). Penerapan Model Pembelajaran TGT untuk meningkatkan hasil belajar siswa, terbitan Universitas Malang; begitu juga Sularmi (2011) PTK guru SD Kemdiknas Musi Rawas, maupun Susiana, handoko (2011) Universitas Muhammadiyah Surakarta.

TGT merupakan salah satu model pembelajaran Kooperatif yang mudah diterapkan karena melibatkan seluruh siswa tanpa harus ada perbedaan status, melibatkan peran siswa yang mengandung unsure permainan dan penguatan. TGT awalnya dikembangkan oleh David de Vries dan Keith Edward dari metode yang disampaikan John Hopkins (Robert E.Slavin. 2008. Cooperative Learning Teori, Riset dan Praktik). Ada 5 Komponen utama dalam menerapkan metode ini, yaitu: (1) Penyajian Kelas (2) Kelompok (3) Game (4) Tournament (5) Penghargaan Team. Menurut beberapa kajian ilmiah, metode ini secara umum terbukti dapat meningkatkan hasil belajar siswa. Namun, peneliti berpendapat selain metode tersebut menurut jurnal lain juga disebutkan bahwa pemberian reward and punishment, juga terbukti secara efektif mampu meningkatkan hasil belajar siswa. Seperti yang dikemukakan Musfiroh, Kholifatul (2012). Pengaruh pemberian reward and punishment maupun skripsi serta Husen. 2013. Pengaruh Pemberian Reward Terhadap Kemampuan Bertanya Pada Mata Pelajaran Geografi Topik Hidrosfer.thesis, Universitas Negeri Semarang.

Reward and punishment dalam pembelajaran akan sangat ideal dan strategis bila digunakan sesuaidengan prinsip-prinsip belajar untuk merangsang belajar dalam kerangka mengembangkan potensi anak didik.

Dalam kamus bahasa Inggris karangan (Echols,1992:456) Reward diartikan sebagai ganjaran atau penghargaan. Sedangka secara umum reward biasa diartikan sebagai hadiah yang diberikan atau didapatkan dengan mudah, misalnyakuis. Sedangkan Punishment merupakan siksaan atas perilaku yang telah diperbuat, namun didalam pendidikan punishment tidak boleh mengandung unsur siksaan, punishment yang dimaksud di sini adalah pemberian tugas tambahan yang dibebankan kepada siswa agar lebih memahami materi/tugas yang belum dikuasai. Pendidik (guru) hendaknya menguasai metode ini secara benar agar tidak berimplikasi buruk, misalnya seorang pendidik menggunakan kekerasan dalam menegakkan kedisiplinan, sehingga menimbulkan kesalahpahaman yang menjadikan anak trauma dan depresi.

Dari kedua variabel tersebut peneliti meneliti bagaimana pengaruh keduanya jika dilaksanakan secara bersamaan menjadi satu kesatuan (variable $\mathrm{X}_{1}$ ) terhadap hasil belajar siswa.

Selanjutnya peneliti juga ingin mengetahui bagaimana peran motivasi belajar terhadap hasil belajar siswa. Menurut Sujana (2002:39) hasil belajar yang dicapai siswa selain dipengaruhi oleh faktor dari luar (guru, teman atau lingkungan) juga dipengaruhi oleh faktor dari dalam diri yang selanjutnya disebut Motivasi (variable $\mathrm{X}_{2}$ ). Motivasi bisa berasal dari pribadi siswa maupun terpengaruh oleh lingkungan/pembiasaan yang 
Prasetyo, E. Hendrik. 2015. Hubungan Persepsi Penerapan Metode

TGT, Reward and Punishment, dan Motivasi Belajar terhadap Hasil Belajar

Siswa Kelas V SDN I Ngrejo, Tulungagung. Konstruktivisme, 7(2): 119-129.

dilakukan. Dalam penelitian ini Motivasi yang diteliti adalah motivasi belajar siswa yang terpengaruhi oleh factor luar/ pembiasaan yang dilakukan oleh guru melalui metode pembelajaran TGT teknik reward and punishment terhadap hasil belajar siswa.

Setiap proses belajar yang dilaksanakan oleh peserta didik akan menghasilkan suatu produk yang bernama hasil belajar. Hasil belajar bisa berupa peningkatan proses keaktifan belajar maupun kemajuan hasil berupa nilai angka/ prestasi belajar (variable $\mathrm{Y}$ )

Hipotesis: (1) Terdapat hubungan positif antara penerapan metode TGT teknik Reward and punishment terhadap peningkatan hasil belajar siswa. (2) Terdapat hubungan positif antara Motivasi belajar siswa terhadap Hasil Belajar siswa. (3) Terdapat hubungan positif secara bersama-sama penerapan metode teknik TGT teknik Reward and punishment serta motivasi belajar yang ditimbulkan terhadap hasil belajar siswa.

\section{METODE}

Penelitian ini dilaksanakan di SDN I Ngrejo Kecamatan Tanggunggunung Kabupaten Tulungagung tahun ajaran 2014/ 2015. Waktu penelitian dilaksanakan selama \pm 4 bulan yaitu mulai bulan Maret sampai Juni 2015.

Jenis penelitian ini adalah Penelitian Tindakan Kelas dimana peneliti bekerjasama dengan guru kelas untuk memperoleh data hubungan penerapan metode yang diperoleh siswa dikelas dan motivasi belajar terhadap hasil belajar mata pelajaran PKn siswa kelas V SDN 1 Ngrejo kecamatan Tanggunggunung Kabupaten Tulungagung. Populasi penelitian ini berjumlah 34 murid dengan karakteristik 16 siswa laki-laki dan 18 siswa perempuan. Kerjasama dalam penelitian ini meliputi kegiatan perencanaan penerapan metode TGT teknik Reward and punishment, perencanaan skema pembelajaran, sampai pada kegiatan penelitian pengaruh kegiatan tersebut pada siswa.

Prosedur Pengambilan/ Pemilihan Sampel dan Penentuan Unit Analisis dialkukan oleh peneliti bersama Guru kelas secara bersama-sama. Sebelum penelitian dilaksanakan, guru melakukan pembelajaran dengan metode ceramah kemudian data hasil belajar siswa diambil sebagai data awal yang akan digunakan sebagai hasil perbandingan kemajuan hasil belajar siswa.

Pengambilan data selanjutnya berlangsung dalam 2 kali siklus, dimana setiap siklus melalui 3 prosedur pengumpulan data .

\section{Siklus I}

1. Siswa diberi pembelajaran menggunakan model TGT murni, kemudian diberi tes uji kompetensi. Hasil tes dibandingkan dengan hasil belajar sebelumnya yang kemudian untuk diketahui peningkatan hasil belajarnya (berupa angka/ nilai)

2. Siswa diberi angket tentang persepsi penerapan metode TGT pada pembelajaran PKn (sangat senang, senang, kadang-kadang, jarang merasa senang, dan hampir tidak merasa senang) 
3. Siswa diberi angket tentang motivasi belajar untuk mengetahui tingkat motivasi belajar setelah mendapat pengajaran model TGT (Sangat temotivasi, termotivasi belajar, kadang-kadang termotivasi, jarang termotivasi, dan hamper tidak termotivasi)

Adapun uraian langkah-langkah pelaksanaan pembelajarannya adalah sebagai berikut:

Kegiatan Awal

Siswa mendpatakan salam, doa,Presensi siswa, apersepsi, penjelasan

materi dan tujuan pembelajaran yang akan dilakukan

Kegiatan Inti

1. Siswa mendapat penjelasan dari Guru tentang materi kemudian siswa diberi tugas mengerjakan LK secara berkelompok

2. Siswa dibentuk menjadi beberapa kelompok denganjumlah anggota antara 4-5 anggota

3. Siswa mendiskusikan jawaban soal di LK masing-masing kelompok

4. Siswa mendapat pembahasan oleh guru tentang jawaban yang benar.

5. Siswa mempelajari soal secara kelompok guna persiapan Games Tournament

6. Siswa melakukan kegiatan Games dipandu oleh guru melalui kartu soal dan jawaban yang dipegang oleh guru.

11. Siswa secara rebutan menjawab setiap soal yang dibacakan oleh guru hingga kartu soal dan jawaban terselesaikan

12. Anggota team yang menang mendapat penghargaan verbal dari guru dan penilaian proses yang tinggi

Catatan: langkah-langkah ini bisa disesuaikan menurut keadaan di kelas tempat pengujian

13. Setelah games, siswa diberi soal uji kompetensi untuk mengukur keberhasilan pembelajaran dan pemahamn siswa secara Individu

14. Pembahasan soal dan penilaian kinerja

Kegiatan Akhir

Refleksi, tindak lanjut/ penugasan

\section{Siklus II}

Prosedur pada siklus ke 2 pada umumnya sama, namun Pada dilakukan penambahan kondisi Reward and punishment pada pembelajaran karena alasan: (1) Penambahan Reward and punishment perlu diterapkan karena pada siklus 1 peneliti menemukan data dokumentasi bahwa ada sebagian siswa yang relative berkemampuan rendah hampir tidak termotivasi untuk ikut kedalam proses pembelajaran, sehingga Reward and punishment diajukan peneliti untuk menanggulangi aspek tersebut. (2) adanya asumsi bahwa penerapan model TGT jika dibarengi teknik Reward and punishment akan lebih berpengaruh positif terhadap motivasi maupun hasil belajar siswa, baik bagi siswa yang bermasalah belajar maupun siswa yang berprestasi. 
Prasetyo, E. Hendrik. 2015. Hubungan Persepsi Penerapan Metode

TGT, Reward and Punishment, dan Motivasi Belajar terhadap Hasil Belajar

Siswa Kelas V SDN I Ngrejo, Tulungagung. Konstruktivisme, 7(2): 119-129.

Sumber data pada penelitian ini menggunakan seluruh populasi sebagai sampel, dikarenakan jumlah populasi yang tidak terlalu banyak $(<40)$. Dengan pertimbangan ini diharapkan karakteristik dari setiap individu dari populasi dapat terekam dengan baik.Teknik pengumpulan data dilakukan dengan tes, dokumentasi serta angket.

Instrumen yang dipakai dalam penelitian ini berupa soal uji kompetensi materi mata pelajaran PKn, Dokumentasi keaktifan siswa saat kegiatan pembelajaran yang mencerminkan motivasi siswa, serta data angket sebagai pembanding dokumentasi yang didapat.

Pengolahan dan Analisis Data dalam penelitian ini menggunakan uji asumsi klasik Regresi Ganda yang mencakup uji normalitas, Uji linieritas, heteroskedastisitas, auto korelasi dan multikolonieritas dengan bantuan computer program SPSS. Tahap uji hipotesis ke 1 dan 2 dilakukan dengan melihat signifikansi sumbangan efektif masing-masing variable bebas terhadap variable tergantung dan hipotesis ke 3 menggunakan multi Regresi dengan melihat signifikansi koefisien dan besarnya $r$ squere.

\section{HASIL DAN BAHASAN}

Dari hasil akhir penelitian (siklus 2) pembelajaran yang dilakukan oleh murid, data pengamatan/ dokumentasi serta data angket, diperoleh hasil sebagai berikut:

Deskripsi data angket persepsi penerapan metode TGT teknik Reward and punishment $\left(\mathrm{X}_{1}\right)$ terhadap siswa diperoleh skor minimum 60,00 maksimum 80,00 skor rata-rata 70,47 Standar Deviasi 5,32 median 71,50 dan modus 74,00.

Deskripsi data angket persepsi motivasi belajar $\left(\mathrm{X}_{2}\right)$ terhadap siswa diperoleh skor minimum 70,00 maksimum 83,00 skor rata-rata 76,58 Standar Deviasi 3,63 median 76,00 dan modus 76,00.

Deskripsi nilai hasil belajar siswa $(\mathrm{Y})$ terhadap siswa diperoleh skor minimum 65,00 maksimum 85,00 skor rata-rata 76,47 Standar Deviasi 5,57 median 75,00 dan modus 75,00.

Peningkatan rata-rata hasil belajar per siklus dalam penelitian ini dapat terlihat sebagai berikut:

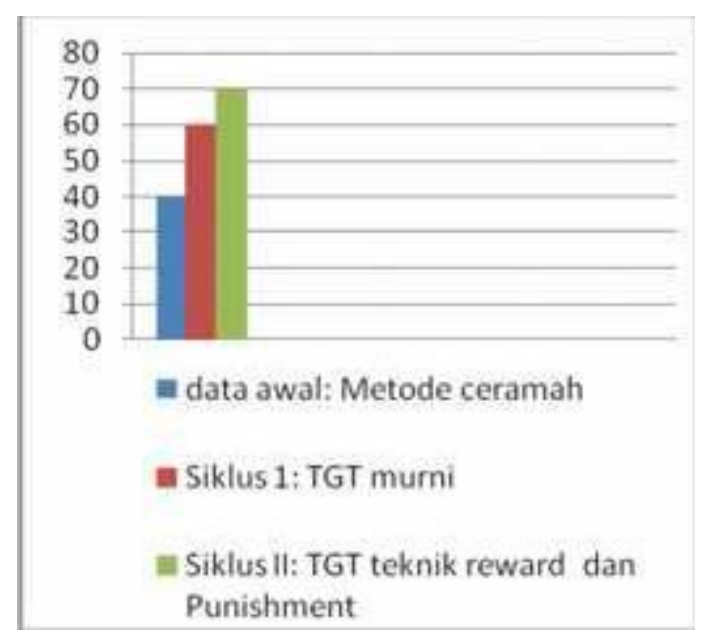

Grafik 1.Perbandingan rata-rata hasil belajar siswa 
Sedangkan keefektifan peningkatan indek skor minimum terlihat sebagai berikut:

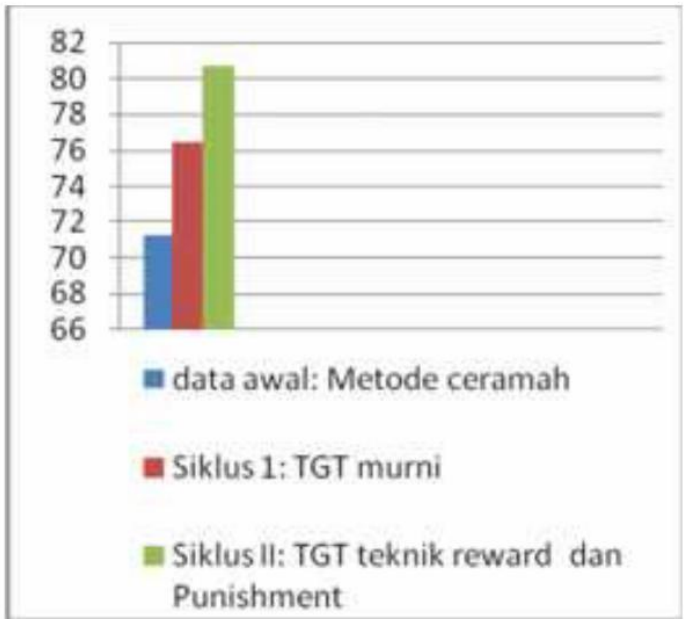

\section{Uji Persyaratan Analisis}

\section{a. Uji Normalitas}

Pengujian distribusi data menggunakan grafik P-P Plots menunjukkan bahwa titik-tik menyebar disekitar garis diagonal (berdistribusi normal) dari output histogram menunjukkan bahwa kurva menyerupai lonceng terbalik dan mendekati kurva normal. Ini berarti data berdistribusi normal.

\section{b. Uji Linearitas}

Hasil pengujian linearitas datadidapat kesimpulan a) hubungan persepsi siswa tentang penerapan metode bersifat linear; b) hubungan motivasi belajar dengan hasil belajar bersifat linear;

\section{c. Uji Multikolinearitas}

Besaran VIF dan tolerance berpedoman pada regresi yang bebas dari multikoliearitas apabila mendekati angka 1 (Santoso, 2005:240) jika Nilai VIF mendekati angka 2, maka variable independent menunjukkan adanya korelasi (Trihandadi 2006:35) dengan hasil analisis sebesar 1,7157 maka dapat disimpulkan bahwa ada korelasi antar variable independent. Terjadi hubungan antara persepsi penerapan metode dan motivasi belajar yang berpengaruh berganda terhadap hasil belajar.

\section{d. Uji Heteroskedastisitas}

Dari hasil output scatterplot, titik-titik terpencar dan tidak membentuk suatu pola tertetu, maka memenuhi asumsi heteroskedastisitas, hal ini sesuai pendapat santosa (2005:243) yang menyebutkan jika tidak ada pola tertentu atau tidak membentuk pola tertentu yang teratur maka dipenuhi asumsi heteroskedastisitas. 
Prasetyo, E. Hendrik. 2015. Hubungan Persepsi Penerapan Metode 125 TGT, Reward and Punishment, dan Motivasi Belajar terhadap Hasil Belajar Siswa Kelas V SDN I Ngrejo, Tulungagung. Konstruktivisme, 7(2): 119-129.

\section{Uji Regesi}

\section{a. Analisis Regresi}

Nilai signifikansi seharunya lebih kecil dari alpha $5 \%$ atau 0,05 , dari data diperoleh bahwa:

1. Nilai konstanta adalah sebesar $-30,165$ dengan $s i g=0,003$ hal ini menunjukkan bahwa data penelitian signifikan.

2. Data koefisien slope penerapan metode TGT teknikReward and punishment $\left(X_{1}\right)$ sebesar 0,175 dengan sig=0,394 hal ini menunjukkan penerapan metode tidak signifikan terhadap hasil belajar, hal ini sesuai dengan asumsi awal bahwa Motivasi belajarlah yang dapat meningkatkan hasil belajar siswa, disini tugas guru dalam menyusun pembelajaran yang efektif kreatif dan menyenangkan sangatlah perlu dilakukan, sehingga penerapan metode ini mampu meningkatkan motivasi belajar siswa.

3. Koefisien slope motivasi belajar sebesar 1,231 dengan sig $=0,000$, hal ini berarti motivasi belajar signifikan terhadap hasil belajar siswa.

\section{b. Sumbangan Relatif}

Melalui uji data Standardized Coefficients beta dan koefisien korelasi diketahui sumbangan relatif (perkalian antara beta dan koefisien korelasi) sebagai berikut:

1. Persepsi siswa tentang penerapan model pembelajaran TGT teknik Reward and punishment memberikan sumbangan relative 0,301655 atau sebesar $30,1655 \%$ terhadap motivasi belajar siswa dansumbangan relative sebesar 0,102705 atau sebesar 10,2705\% terhadap hasil belajar.

2. Motivasi belajar memberikan sumbangan relative sebesar 0,774895 atau sebesar $77,4895 \%$ terhadap hasil belajar

3. Penerapan metode TGT teknik Reward and punishment serta motivasi belajar yang ditimbulkan terhadap hasil belajar siswa memberikan sumbangan relative sebesar 0,8776 atau $87,76 \%$

\section{c. Model Regresi}

$\mathrm{X} 1=0,175$

konstanta $-30,165$

$\mathrm{X} 2=1,231$

Sehingga diperoleh persamaan Regresi $Y=-30,165+0,175 X_{1}+1,23 X_{2}$

1. Konstanta sebesar $-30,165$ menyatakan bahwa jika tidak ada kenaikan nilai dari variable persepsi siswa tentang penerapan metode TGT teknik Reward and punishment, maka hasil belajar mata pelajaran PKn yang diperoleh siswa adalah 30, 165

2. Koefisien $0,175 X_{1}$ menyatakan bahwa setiap penambahan 1 angka dari persepsi siswatentang penerapan metode TGT teknik Reward and punishment, maka akan meningkatkan hasil belajar mata pelajaran PKn yang diperoleh siswa sebesar 0,175

3. Koefisien $1,231 \mathrm{X}_{2}$ menyatakan bahwa setiap penambahan 1 angka dari persepsi siswatentang penerapan metode TGT teknik Reward and 
punishment, maka akan meningkatkan hasil belajar mata pelajaran PKn yang diperoleh siswa sebesar 1,231

4. Koefisien $X_{2}$ lebih besar dari koefisien $X_{1}$ Ini berarti bahwa motivasi belajar lebih dominan pengaruhnya dibandingkan dengan persepsi siswa tentang penerapan metode TGT teknik Reward and punishment.

\section{Uji Hipotesis dari table correlations model summary}

1) Koefisien Korelasi Pearson antara persepsi siswa tentang penerapan metode TGT teknik Reward dengan hasil belajar siswa adalah 0,946 dengan sig=0,000. Karena nilai signifikansi lebih kecil dari $a=5 \%(0,05)$ maka $\mathrm{H}_{\mathrm{o}}$ ditolak dan $\mathrm{H}_{\mathrm{a}}$ diterima. Hal ini berarti ada pengaruh yang signifikan antara persepsi siswa tentang penerapan metode TGT teknik Reward and punishment dengan hasil belajar siswa

2) Koefisien Korelasi pearson antara Motivasi belajar dengan hasil belajar siswa adalah 0,965 dengan sig=0,000. Karena nilai signifikansi lebih kecil dari $\mathrm{a}=5 \%(0,05)$ maka $\mathrm{H}_{\mathrm{o}}$ ditolak dan $\mathrm{H}_{\mathrm{a}}$ diterima. Hal ini berarti ada pengaruh yang signifikan antara motivasi belajar dengan hasil belajar siswa.

3) Koefisien determinansi dari persamaan regresi ( $r$ squre) adalah 0,932. Dengan demikian berarti persepsi siswa tentang penerapan metode TGT teknik Reward and punishment serta motivasi belajar memberikan sumbangan sebesar 0,932 terhadap hasil belajar siswa. Ini berarti sebanyak 93,2\% variasi atau perubahan hasil belajar mata pelajaran PKn dapat dijelaskan oleh variasi atau perubahan hasil belajar siswa serta motivasi belajar. Atau dengan kata lain, sebanyak $6,8 \%$ variasi atau perubahan hasil belajar diakibatkan oleh factor lain. Sedangkan jika dilihat dari analisis Anova diketahui $F$ hitung adalah 213,790 engan sig $=0,000$, maka nilai $F$ signifikan secara statistic, sehingga model regresi dapat dipakai untuk memprediksi peningkatan hasil belajar melalui penerapan metode TGT teknik Reward and punishment serta motivasi belajar siswa.

Dari hasil uji hipotesis pertama didapat bahwa persepsi siswa tentang penerapan metode TGT teknik Reward and punishment berpengaruh secara signifikan terhadap hasil belajar mata pelajaran PKn

pada siswa, dengan koefisien korelasi 94,6\%. Hasil penelitian ini memperkuat teori yang menyatakan bahwa penerapan model TGT maupun teknik pemberian Reward and punishment dapat meningkatkan hasil belajar siswa.

Dari hasil uji hipotesis kedua didapat bahwa motivasi belajar secara signifikan terhadap berpengaruh terhadap hasil belajar mata pelajaran PKn pada siswa.Hal ini mendukung pendapat Winataputra (1994:16) yang menyatakan bahwa "motivasi akan menentukan tingkat berhasil atau kegagalan perbuatan belajar siswa.Belajar tanpa motivasi kiranya sulit untuk berhasil". Hal ini berarti, jika siswa mempunyai motivasi belajar yang baik, maka hasil belajarnya juga akan baik,begitu pila sebaliknya.

Dari hasil uji hipotesis ketiga, didapat bahwa Variabel X1 dan X2, secara nyata, sah dan meyakinkan memberikan sumbangan 93,2\% terhadap peningkatan hasil belajar siswa. Walaupun factor Motivasi belajar 
lebih dominan, namun didalam motivasi ini juga terlihat dipengaruhi oleh faktor penerapan metode, sehingga dapat disimpulkan bahwa keduanya mempunyai pengaruh yang positif terhadap peningkatan hasil belajar siswa, dan hasil kajian ini semoga dapat dikembangkan untuk materi atau pelajaran lain sebagi sumbangsih pemikiran penulis.

\section{SIMPULAN DAN SARAN}

Berikut temuan-temuan penelitian berdasarkan hasil penelitian dan pembahasan. Walapun penelitian ini dianalisi menggunakan data kuantitatif, namun dalam prosesnya, dikarenakan penelitian ini berupa penelitian tindaklan kelas, ada bebarapa temuan kualitatif yang dapat kita pelajari di antaranya:

1). Terdapat peningkatan keaktifan guru dan siswa dalam proses belajar mengajar yang terbukti diakhir siklus dapat menghantarkan siswa didik dalam meningkatkan hasil belajarnya

(2). Terdapat peningkatan kegairahan/ motivasi anak didik untuk mengikuti pembelajaran, hal ini diketahui dari hasil wawancara secara sampling terhadap 5 siswa secara acak, diketahui 4 diantaranya mengaku senang terhadap metode yang diperankan oleh guru

(3) Secara nyata penerapan Metode tidak hanya berpengaruh pada penilaian produk tetapi juga berpengaruh terhadap penilaian proses.

(4) Metode TGT sendiri sebenarnya sudah cukup dapat meningkatkan hasil belajar siswa, begitu juga dengan teknik reward and punishment.

Namun ada kelemahan disetiap metode tersebut, misalnya: Metode TGT kurang memperhatikan akibat bagi siswa yang tidak aktif dalam pembelajaran, sehingga perlu adanya penambahan unsur punishment. Sedangkan teknik reward and punishment memerlukan suatu kegiatan game yang menyenangkan. Sehingga keduanya layak digabungkan dan terbukti Ketika keduanya digabung, secara nyata dapat lebih meningkatkan motivasi dan hasil belajar siswa di kelas.

Kesimpulan Data Akhir Penelitian

1) Terdapat hubungan positif (signifikan) antara penerapan metode TGT teknik Reward dengan peningkatan Hasil belajar siswa dengan koefisien korelasi 0,946

2) Terdapat hubungan positif (signifikan) anatara motivasi belajar dengan hasil belajar siswa dengan koefisien korelasi 0,965

3) Terdapat hubungan positif (signifikan) secara bersama-sama penerapan metode TGT teknik reward dan motivasi belajar yang ditimbulkan terhadap hasil belajar siswa, dengan koefisien korelasi berganda sebesar 0,844 . Dengan sig=0,000 lebih kecil dari $\mathrm{a}=5 \%(0,05)$ maka $\mathrm{H}_{\mathrm{o}}$ ditolak dan $\mathrm{H}_{\mathrm{a}}$ diterima. Hasil belajar rata-rata siswa mengalami peningkatan dari siklus I dan siklus 2 dari nilai rata-rata (mean) 76,47 menjadi 80,734 indek skor minimum meningkat dari 65 menjadi 70 . Saran teoritis tindak lanjut untuk pengembangan ilmu pengetahuan dari penulis adalah:

1. Beberapa metode kadang mempunyai karakteristik yang hampir sama maupun berbeda namun mempunyai tujuan akhir yang sama yaitu 
peningkatan hasil belajar siswa didik. Penggabungan beberapa metode atau teknik pembelajaran dapat selalu dilakukan oleh guru guna mencapai tujuan tersebut.

2. Bagi Guru PKn di SD hendaknya dapat menerapkan metode TGT teknik reward dalam proses pembelajaran

3. Bagi orang tua dan pihak sekolah hendaknya dapat terus meningkatkan motivasi belajar siswa, karena motivasi belajar siswa tidak hanya berasal dari guru, tetapi juga berasal dari keluarga

4. Bagi Dinas Pendidikan dan Pengawas bidang studi hendaknya dapat membuat suatu program yang dapat meningkatkan pemahaman guru dalam penerapan model-model pembelajaran khususnya model pembelajaran Team Games Tournament.

5. Bagi peneliti lain diharapkan dapat meneruskan penelitian ini dengan mengkaji ruang lingkup yang lebih luas atau wilayah lain.

\section{DAFTAR PUSTAKA}

Arikunto, Suharsimi. 2003. Manajemen Penelitian.Jakarta: PT.Rineka Cipta Belajar Psikologi. Com. 2012. Pengertian Motivasi Belajar.

(http://belajarpsikologi.com/pengertian-motivasi-belajar/,diakses September 2015.

Budiono. 2004. Statistika Untuk Penelitian.Surakarta : Sebelas Maret University Press.

Dawes, John. 2008. Do Data Characteristics Change According to the number of scale points used? An Experiment using 5-point, 7-point and 10-point scales. International Journal of Market Research, 50 (1), 61-77.

Departemen Pendidikan Nasional. 2006. Standar Kompetensi Mata Pelajaran Pendidikan Kewarganegaraan SD dan MI. Jakarta : Puskur Balitbang Depdiknas.

Echols,John. 1992. Kamus Bahasa Inggris.

Hana, Dian Sri Noor. 2011. Pengaruh Motivasi Belajar dan Partisipasi Belajar Warga Belajar terhadap Hasil Belajar Pada Mata Pelajaran Sosiologi (Studi Kasus Warga Belajar Kejar Paket C DI PKBM Ngudi Kawruh Kecamatan Banyumanik). Semarang : Under Graduates thesis, Universitas Negeri Semarang.

Husen. 2013. Pengaruh Pemberian Reward Terhadap Kemampuan Bertanya Pada Mata Pelajaran Geografi Topik Hidrosfer.Skripsi.Jurusan Fisika, Prodi. S1 Geografi, Fakultas Matematika dan Ilmu Pengetahuan Alam, Universitas Negeri Gorontalo

Kasriyatun. 2011. "Pengaruh Motivasi Belajar dan Persepsi Siswa Tentang Profesionalisme Guru Terhadap Hasil Belajar Akuntansi Pada Siswa Kelas XI Sekolah Menengah Atas Negeri 1 Kartasura Tahun Ajaran 2009/2010", Surakarta : Skripsi Thesis, Universitas Muhammadiyah.

Musfiroh, Kholifatul. 2012. Pengaruh Pemberian Reward and punishment Terhadap Minat BelajarSiswa.Skripsi. STAIN Salatiga

Nashar. 2004. Penerapan Motivasi dan Kemampuan Awal dalam Kegiatan Pembelajaran. Jakarta : Delia Press. 
Prasetyo, E. Hendrik. 2015. Hubungan Persepsi Penerapan Metode 129 TGT, Reward and Punishment, dan Motivasi Belajar terhadap Hasil Belajar Siswa Kelas V SDN I Ngrejo, Tulungagung. Konstruktivisme, 7(2): 119-129.

Nasution. 2006. Kurikulum dan Pengajaran.Jakarta : Bumi Aksara.

Nisa, Chadhirun Asnif Fdhlun. 2009. Pengaruh Motivasi Belajar Terhadap

Hasil Belajar Siswa pada Mata Pelajaran Akuntansi di SMA Islam

Malang. Malang: Skripsi, Jurusan Akuntansi Program Studi

Pendidikan Akuntansi Fakultas Ekonomi Universitas Negeri Mlang.

Pratiwi. 2009. Panduan Penelitian Skripsi.Yogyakarta : Tugu Publishes.

Robert E. Slavin. 2008. Cooperative Learning Teori, Riset dan Praktik.

Bandung: Nusa Media.

Sadirman. 2004. Interaksi dan Motivasi Belajar.Jakarta : PT Rineka Cipta.

Sularmi. 2011. Meningkatkan Hasil Belajar IPS Siswa Kelas VI SD Negeri

Sidoharum Kabupaten Musi Rawas melalui Model Kooperatif Team

Games Tournament (TGT)". Musi Rawas: PTK Guru SD Kementerian Pendidikan Nasional Musi Rawas.

Susiana, Handoko. 2011. Penerapan metode Team Games Tournament untuk Meningkatkan Hasil Belajar IPS Pada Siswa kelas IV SDN Gentan 01 Kecamatan Baki Kabupaten Sukoharjo Tahun Pelajaran 2011/2012. Surakarta: Skrpsi Universitas Muhammadiyah Surakarta.

Winataputra. 1994. Motivasi Belajar Siswa.Jakarta: Gramedia.

Yudianto, Arif. 2001. Penerapan Model Pembelajaran Team Games Tournament (TGT) untuk menimgkatkan hasil belajar siswa mata pelajaran IPS kelas VI di SDN Tlogosari 01 Kecamatan Tirtoyudo Kabupaten Malang". Malang: Skripsi Universitas Negeri 1 Malang. 